\title{
PUBLIC AND LEGAL RELATIONS AS A SPHERE OF JUDICIAL PROTECTION OF VIOLATED RIGHTS, FREEDOMS, AND INTERESTS
}

\author{
Vyacheslav Tylchyk', Viktor Leschynsky²
}

\begin{abstract}
The role of legal relations in legal science cannot be overestimated, especially given the expansion of the boundaries of the subject of administrative law, which leads to the need to rethink its content. Legal relations can be defined as a kind of phenomenon that is a sign of a systemic connection and includes law in its subjective and objective sense. This is due to the fact that the law without legal relations loses its practical meaning, even in the case of certain material leverage. An important statement in the context of scientific research is that law is a real element of public life only when its existence is mediated by legal relations. It is clear that the sphere of public and law relations is much narrower in terms of the volume of social relations in general, which are due to the presence of phenomena that, crystallizing through the prism of legal regulation, acquire legal consolidation and significance. Analysing social relations (individual phenomena, institutions), scientists automatically transfer them to the legal plane. In this case, it is not possible to state the equal importance of social relations and law in legal relations, because the first will fill the legal gaps that will be the cornerstone of their order, and the conceptual apparatus of such a system will have to affect the legal form of law enforcement or vice versa. The reflexivity of a person's perception of social norms expressed in the balance of social relations and law in legal relations can be established only by analysing not only legal norms but also social relations, which they organize in a "volumetric" sense. It is clear that such a process should not turn into a mechanical increase in legal regulation, but take into account the peculiarities of social relations, which, in fact, indicate anthropocentrism rather than the fact of priority or importance for the state as a subject (participant). In this context, it should be noted that today it is extremely difficult to determine which relations are most important for the state; moreover, the balance of human-centrism seems unclear, because without the participation of public authorities in the declared "self-regulation" to reach any "stability" whether it is impossible to overcome the negative phenomena. Methodology. The solution of the tasks is carried out using the cognitive potential of the system of philosophical, general scientific and special methods. Constitutionalism and synthesis allowed to define attributes and essence of the concept of "public law relations" and create this and other concepts. Using the form of analysis - systematization - the problems of classification of disputes in the field of public relations are identified, which are resolved by administrative courts. The structural and functional method is used during the characterization of public and law relations as a sign of a dispute, which is resolved in administrative proceedings and the study of the structure of the judicial administrative process. Methods of linguistic analysis and interpretation of legal norms helped identify gaps and other shortcomings in the legislation, develop proposals for its improvement.
\end{abstract}

Key words: public and legal relations, guarantees of legality, dispute in the field of public and legal relations, administrative proceedings and administrative process, subject of own powers, judicial protection.

JEL Classification: K10, K40, K49

\section{Introduction}

Along with a number of positive changes to the wording of regulations during the last judicial reform, the legislator has not paid attention to certain terms that can provide a single approach to understanding the law enforcement key criteria. This thesis primarily

\footnotetext{
Corresponding author:

${ }^{1}$ University of the State Fiscal Service of Ukraine, Ukraine

E-mail: tilchikvv@ukr.net

ORCID: https://orcid.org/0000-0001-5964-3439

${ }^{2}$ Institute of Innovative Education of Kyiv National University of Construction and Architecture, Ukraine;

National Expert Building Alliance of Ukraine, Ukraine

E-mail: le_v@ukr.net
} 
concerns the concept of "public law relations". This notion is really a cornerstone, as administrative justice in general aims to protect the rights and interests of individuals (natural persons and legal entities) only if they are violated in the field of public relations. In the interests of effective administrative proceedings, a common vision of the nature of public law relations is of paramount importance for both the individual and the judge. According to V.B. Averianov (2011), the lack of normative interpretation of the concept of these relations in the Code of Administrative Judicial Proceedings of Ukraine (hereinafter referred to as CAJP of Ukraine) does not contribute to such unity.

This problem is doctrinal because among the novels this concept has not been formulated in CAJP of Ukraine (2005), so the criterion that should identify the dispute as one that arose in the field of public relations becomes the subject of more epistemological conclusions of judges than normative legal reality. It should be noted that the lack of a formulated concept of "public relations" does not allow to define derived concepts, for example, "disputed public relations", and so on.

\section{Scientific and normative approaches to determining criteria at public law relations}

V.M. Kravchuk (2013) emphasizes the sufficiency of two criteria (substantive and subjective). According to the substantive criterion, civil, commercial, and administrative jurisdictions are distinguished. Business cases arise between legal entities and entrepreneurs, as well as on the creation and termination of legal entities (corporate disputes), and administrative include the participation of the subject of power. All other cases (disputes) are resolved in civil proceedings. According to the subjective criterion, jurisdiction is divided into constitutional, civil (including economic and administrative), and criminal. In most cases, this distribution is not a problem. Each of these types of proceedings has its own purpose, which determines such features of the proceedings that cannot be unified (Kravchuk, 2013). Despite this provision, the exclusive list of criteria for determining the subject (an unambiguous affiliation of the dispute) of the judicial administrative jurisdiction is considered insufficient, as evidenced by "ardent" scientific discussions.

Criteria are conditionally standardized, as already noted in Article 4 of CAJP of Ukraine in determining the dispute in the field of public relations and Article 19 of CAJP of Ukraine (Code of Administrative Judicial Proceedings of Ukraine, 2005). The content of the latter allows scholars and practitioners to draw conclusions about the scope and nature of public relations, as well as their subjective composition (or vice versa) as illustrated by the above provisions.
According to Article 19 of the Criminal Procedure Code of Ukraine, the jurisdiction of administrative courts extends to the above disputes, Code of Administrative Judicial Proceedings of Ukraine (2005). The analysis of this article makes it possible to conclude that its regulatory action concerns parts of the legal structure "dispute in the field of public relations". "Dispute" is normatively defined as "violation" in the form of performance or non-performance by the subject of the power of these functions, provision or non-provision of administrative services, other violations of the rights of a person - the subject of the election or referendum process (CAJP of Ukraine, 2005). At the same time, the content of this article does not contain a complete list of forms of encroachment decisions, actions, and omissions, in particular, it is not about other facts that are subject to verification in administrative proceedings (paragraph 2 of Article 2 of CAJP of Ukraine, 2005).

Instead, parts 1-15 of the first paragraph of Article 19 of CAJP of Ukraine (2005) present an updated list of disputes on nature (content) of public law relations within which they arise. The analysis of the specified norms allows to state that the mentioned norms of CAJP of Ukraine regulate the same legal relations which are connected with a legal construction "dispute in the field of public law relations". This legal structure should include the subject of power, the presence of which is mediated as a sign of the concept of "public law relations", and on the other - as a party to the encroachment on the object of judicial protection (rights, freedoms, interests).

Logical is the selection of the following criteria: forensic administrative jurisdiction is used in case of the presence of the government entity whose activities are connected, including power management functions, as well as individuals or legal entities of public and private law, collective entities without legal personality, endowed (temporary) administrative powers or the use by the subject of the power of instruments of public administration. It should be noted at once that the formation of a "mixed" criterion "the subject of power and the implementation of its respective functions (or powers)" along with the criterion of the presence of "subject of power" seems more appropriate, which is explained by the dynamics and statics public relations.

Its use (the criterion of application of power by the subject) alone or in combination with another, with one separate criterion, seems impractical, given its evaluative nature, which is indicated by scientists (Averianov, 2010).

Along with this, the selection of this criterion makes it possible to draw conclusions (possibly not final) on the nature of activities (e.g., administrative) of the subject of power in other areas of public relations (tax, land, election, criminal, etc.). Moreover, the 
application of this criterion plays another role - the definition of relations as public law, and the dispute as one that has arisen in the field of public law relations. Properly, violation (issuance of an illegal decision, commission of an illegal act, or admission of illegal inaction) can be characterized only in the implementation of management function(s), which, in turn, will trace the relationship of the category - the subject of power, public law relations and violations, i.e., the existence of a dispute in such relations and the fact of encroachment on the object of judicial protection - the rights, freedoms, and interests of natural persons and legal entities.

Thus, in particular, in case No. 800/301/16 dated November 15, 2016, the Board of Judges of the Judicial Chamber for Administrative Cases of the Supreme Court of Ukraine decided to refuse to satisfy the claims, as they did not concern about the violated rights of the person. The violation must be real, affect the rights, freedoms, or interests of the person at the time of going to court. In fact, the court found no dispute (Resolution of the Supreme Court of Ukraine in case No. 800/301/16 dated November 15, 2016), the absence of violation of the right of a person also precluded the resolution of the dispute on the merits (Resolution of the Grand Chamber of the Supreme Court in case No. 802/2474/17-a dated December 12, 2018).

It should be summarized that in order for the criterion of "exercise of power by the subject" to play a more significant role in determining the subject of the jurisdiction of the administrative court, it is necessary to normalize the relations arising in the process of such activities. One of the proposed options is the adoption of the Administrative and Procedure Code of Ukraine or another form, but essentially the same in essence as the legal act.

Thus, the Draft Administrative and Procedure Code of Ukraine (hereinafter referred to as the Draft Code) uses the term "individual administrative case" (administrative case), a case on the implementation and protection of the rights, freedoms, and legitimate interests of individuals, and legal entities, including the provision of administrative services, which is considered by the authorized entity in accordance with this Draft Code. Under the authorized subject we understand the body of executive power, local government and their officials, who are authorized to consider and resolve administrative cases in accordance with their competence (it is clear that the list of subjects of power will be established in accordance with the scientific advances of administrative law and practice at the time of adoption of such a legal act).

It is necessary to specify the elements of public law relations (including administrative) as they arise in the process of solving the "administrative proceedings", result (form or tool is selected from the motives of the ambiguous approach established in legal science) is to take "administrative" decisions, actions or inaction. The use of the term "administrative" in such conditions will determine the automatic assignment of decisions (actions, omissions) to the subject of the jurisdiction of the administrative court in the presence of violations of rights, freedoms, etc. of citizens by the authorities competent to decide such a case. It is also appropriate to use the term "administrative case", because in this case the process of fixing the facts concerning the need for adoption, validity, prudence, good faith, impartiality, "administrative decision" will perform the primary function of such entities. In this context, it is also necessary to emphasize the complexity of such a process, as resolving the issue of a clear definition of administrative jurisdiction in this way may contribute to a more complex problem - a clear definition of the jurisdiction of subjects of power. Despite the above, we believe that in this case the decisive role will be played by the sustainability of the judicial practice.

Regarding the following criterion "the existence of rules governing the disputed legal relationship", it should be noted that T.O. Kolomoiets (2009) emphasized the use of the method of administrative and legal regulation to determine the nature of disputed legal relations and court proceedings, when considering them, as all public law relations arise on the basis of legal norms, and therefore the disputes can be called public. However, when distinguishing administrative jurisdiction from other types of jurisdiction, it is not necessary to absolutize the importance of the relationship that is the object of public administration. The latter has a universal character, i.e., extends its influence to most sectors of society, which are traditionally grouped into three spheres - economics, social and cultural, administrative and political. The competence of administrative courts in Ukraine covers the control of public administration activities in all these areas. Proponents of the association in the economic jurisdiction of both private and public disputes suggest removing from the jurisdiction of administrative courts management in one of these areas, which cannot be considered natural and scientifically sound because there is no reason for this - in all areas the same set of forms and methods of public administration is used, which only partially depends on the content of managed relations (Kolomoiets, 2009).

In this context, M.P. Kucheriavenko and N.L. Shevtsova (2012) point to the need to develop a unified approach in referring, in particular tax disputes, to administrative jurisdiction. Tax disputes, as well as tax relations in general, should be of the same type. It is impractical to break the unified system in different types of jurisdictions. At the same time, tax disputes (all without exception) on the basis of orientation and connection with economic activity are difficult to attribute to a single group. The criteria for differentiation are quite traditional: 
the subjective composition and nature of the disputed legal relationship. However, they are applied in some cases in such a way that it is difficult to agree with it, even though such a problem is now clearly resolved and indicates the attribution of such disputes to administrative jurisdiction based on the public law nature of tax relations.

\section{Alternative criteria for the identification of public law relations as a sphere of protection of violated rights, freedoms and interests}

The existence of such a problem in other categories of disputes is emphasized by a large number of scholars and practitioners. In particular, A.O. Monaienko (2019) points out that such categories of cases that lead to jurisdictional disputes are disputes with the state registrar regarding real estate rights, where his or her registration actions are challenged; land disputes with local governments as subjects of power or economic entities; disputes with the Deposit Guarantee Fund of individuals; disputes over the organization and conduct of public procurement by subjects of power, etc. It is obvious that the problems that arise in the process of identifying administrative or other types of judicial jurisdiction are primarily related to the superficial application of criteria without a thorough analysis. This situation can be explained, in particular, by the excessive burden on judges.

In addition, it is necessary to point to such a criterion of delimitation of administrative jurisdiction as "the presence and/or absence of a special procedure for resolving disputes in the field of public relations", which logically follows from the rules of CAJP of Ukraine. Thus, paragraph 1 of the first part of Article 19 of the Criminal Procedure Code of Ukraine states that disputes of individuals or legal entities with the subject of authority to appeal its decisions (regulations or individual acts), actions or omissions are resolved by administrative proceedings except when the law establishes a different procedure for the consideration of such disputes. Part 2 of Article 19 of the Criminal Procedure Code of Ukraine provides that the jurisdiction of administrative courts do not extend to disputes that in accordance with paragraphs 1-3, referred to the jurisdiction of the Constitutional Court of Ukraine, are resolved in criminal proceedings, disputes on administrative penalties, except as provided Code. In addition, the third part formed the institute of the derivative claim. Its essence is that administrative courts do not consider claims that are derived from the requirements of a private dispute and filed with them if the dispute is subject to consideration other than administrative proceedings and is pending before the relevant court (CAJP of Ukraine, 2005). Therefore, the clarifying criterion to the criterion "presence and/ or absence of the procedure for resolving the dispute" should be recognized as the "nature of the claims". The normative definition of this criterion, as a rule, is as follows: in accordance with Article 55 of the Constitution of Ukraine, a person's right to access to justice is guaranteed. The application of this article was explained by the Supreme Court of Ukraine in the Plenum "On the Application of the Constitution of Ukraine in the Administration of Justice" No.9 dated November 1, 1996, in particular in Part 8. Here it was emphasized that taking into account the constitutional provision justice in Ukraine - applies to all legal relations arising in the state (Article 124 of the Constitution), the courts have jurisdiction over all disputes concerning the protection of the rights and freedoms of citizens.

The Administrative Court hears cases and resolves disputes in the field of public law relations only on the basis of a statement of claim filed in accordance with the rules of CAJP of Ukraine, within the claims stated in it (part 2 of Article 9 of CAJP of Ukraine, 2005). Paragraph 4 of part 5 of Article 160 of CAJP of Ukraine (2005) in the statement of claim indicates the content of the claims and a statement of the circumstances in which the plaintiff substantiates its claims. The grounds for closing the proceedings, and the signs of the above criterion, are determined by part 1 of Article 170 of CAJP of Ukraine (CAJP of Ukraine, 2005). These include: in a dispute between the same parties, on the same subject and on the same grounds, there are those that have entered into force, a court decision or ruling, a decision to close the proceedings; the death of a natural person has occurred or a legal entity that is not a subject of power has been terminated, which has filled a statement of claim or to which a statement of claim has been filled if the disputed legal relationship does not allow succession; in the proceedings of this or that court, there is a case of a dispute between the same parties, on the same subject and on the same grounds.

We agree with Ya.O. Bernaziuk (2019), who, analysing the claims, identifies disputes that are not subject to litigation at all. Such disputes include disputes over claims: to the President of Ukraine or the Verkhovna Rada of Ukraine as political bodies formed by all-Ukrainian elections, a claim does not relate to the direct management activities of these subjects of power; in which the applicant has chosen an ineffective (premature) method of protection in the presence of an alternative effective method of protection; in which the applicant has chosen a non-legal (artificial) method of protection; in which the applicant has chosen a method of protection for which the law defines a special procedure or imposes restrictions on the subject of the application with the relevant claim (Bernaziuk, 2019). These conclusions are made on the basis of the analysis of case law (Resolutions of the Grand Chamber of the Supreme Court: case No. 800/559/17 dated March 22, 2018, case No. 9901/152/18 dated April 3, 2018, case No. 9901/497/18 dated May 30, 
2018), etc. In most cases, the claims set out in the statement of claim concerned mainly the incorrect choice of the method (normatively determined procedure) of judicial protection.

\section{Conclusions}

The synthesis of knowledge about public law relations is an element of the content of the science of administrative law; therefore, it is an object of scientific interest and a vector of formation of modern legal doctrine. The complexity of the study of this category is due to the fact that the regulation of public relations is carried out in the constant development of management systems and in close connection with the main purpose of their operation - ensuring public interests and guaranteeing human rights in accordance with Article 3 of the Constitution. Along with the above, the condition for disputes in the field of public relations is the conflict of the latter, which is due primarily to the nature of administrative law, as the right of power, based on its main doctrinal features and content, including in particular in the context of real rights, freedoms, and interests of citizens.

\section{References:}

Administratyvno-protsedurnyi kodeks Ukrainy: Proekt [Administrative and Procedure Code of Ukraine: Draft on Law]. Available at: https://minjust.gov.ua/m/str_2734 (accessed 1 March 2021).

Averianov, V. B. (2011). Poniatiino-terminolohichni novely Kodeksu administratyvnoho sudochynstva Ukrainy: dyskusiini problemy [Conceptual and terminological novelties of the Code of Administrative Procedure of Ukraine: debatable problems]. Law of Ukraine, no. 4, pp. 12-39. (in Ukrainian)

Averianov, V. B. (2010). Providna poniatiina novela Kodeksu administratyvnoho sudochynstva Ukrainy: doktrynalnyi analiz [Leading conceptual novella of the Code of Administrative Procedure of Ukraine: doctrinal analysis]. Bulletin of the Supreme Administrative Court of Ukraine, no. 2, pp. 3-15. (in Ukrainian)

Bernaziuk, Ya. O. (2019). Pro pozovy, yaki ne pidliahaiut sudovomu rozhliadu [About claims that are not subject to litigation]. Judicial-legal newspaper. Available at: https://sud.ua/en/news/blog/140426-pro-pozovi-yaki-nepidlyagayut-sudovomu-rozglyadu (accessed 1 March 2021). (in Ukrainian)

Brintsev, O. V. (2013). Do pytannya pro kryterii rozmezhuvannia yurysdyktsii. Visnyk hospodarskoho sudochynstva [On the issue of the criteria for delimitation of jurisdictions]. Bulletin of commercial litigation, no. 6, pp. 63-66. (in Ukrainian)

Kodeks administratyvnoho sudochynstva Ukrainy (2005) [Code of Administrative Judicial Proceedings of Ukraine]. The Verkhovna Rada of Ukraine, number 35-36, number 37, p. 446. Available at: https://zakon.rada.gov.ua/laws/show/2747-15\#Text (accessed 1 March 2021). (in Ukrainian)

Kolomoiets, T. O. (2009). Rozmezhuvannia yurysdyktsiinykh povnovazhen mizh administratyvnymy ta hospodarskymy sudamy: okremi problemy pytannia sohodennia [Separation of jurisdictional powers between administrative and commercial courts: some problems of the present issue]. Bulletin of Zaporizhia National University, no. 1, pp. 69-78. (in Ukrainian)

Kravchuk, V. M. (2013). Metody vyrishennia yurysdyktsiinykh problem [Methods of solving jurisdictional problems]. Available at: http://www.vasu.gov.ua/nkr/nauk_praci/metodi_virish_yurisdikc_problem/ (accessed 1 March 2021). (in Ukrainian)

Kucheriavenko, M. P., \& Shevtsova, N. L. (2012). Kryterii rozmezhuvannia yurysdyktsii [Criteria for delimitation of jurisdiction]. Law and Business, no. 32 (1071). Available at: https://zib.com.ua/ua/print/11020-podatkovi spori gospodarski chi administrativni.html (accessed 1 March 2021). (in Ukrainian)

Monaienko, A. O. (2019). Na styku yurysdyktsii [At the junction of jurisdictions]. Legal newspaper, no. 24. Available at: https://yur-gazeta.com/publications/practice/sudova-praktika/na-stiku-yurisdikciy.html (accessed 1 March 2021). (in Ukrainian)

Podatkovyi kodeks Ukrainy (2010) [Tax Code of Ukraine]. Verkhovna Rada of Ukraine. Available at: https://zakon.rada.gov.ua/laws/show/2755-17 (accessed 1 March 2021). (in Ukrainian)

Postanova Velykoi Palaty Verkhovnoho Sudu v spravi № 9901/798/18 (2019) [Resolution of the Grand Chamber of the Supreme Court in case № 9901/798/18 of 27 February 2019]. Available at: http://reyestr.court.gov.ua/ Review/80364151\# (accessed 1 March 2021). (in Ukrainian)

Postanova Verkhovnoho Sudu Ukrainy vid 15.11.2016 roku u spravi № 800/301/16 [Resolution of the Supreme Court of Ukraine of November 15, 2016 in case № 800/301/16]. Available at: https://protocol.ua/ua/ postanova_vsu_vid_15_11_2016_roku_u_spravi_800_301_16/(accessed 1 March 2021). (in Ukrainian) Postanova vid 12.12.2018 № 802/2472/17-a Verkhovnyi Sud. Velyka Palata [Resolution of 12.12.2018 № 802/2472/17-a Supreme Court. The Grand Chamber]. Available at: https://verdictum.ligazakon.net/ document/78589538 (accessed 1 March 2021). (in Ukrainian)

Pro zastosuvannia Konstytutsii Ukrainy pry zdiisnenni pravosuddia: Postanova plenumu Verkhovnoho Sudu Ukrayiny № 9 (1996) [On the application of the Constitution of Ukraine of justice: The decision of the Supreme Court of Ukraine number 9]. Available at: https://zakon.rada.gov.ua/laws/show/v0009700-96 (accessed 1 March 2021). (in Ukrainian) 